\title{
Pemberian Berbagai Level Eceng Gondok (Eichornia crassipes) dan Minyak Ikan (Centrophorus atromarginatus) dalam Ransum Puyuh terhadap Performa, Kolesterol dan Profil Asam Lemak Telur
}

\author{
The Effect of Various Level of Hyacinth (Eichornia crassipes) Meal and Fish Oil (Centrophorus atromarginatus) Using in \\ Quail Diet on Performance, Cholesterol and Egg Fatty Acid Profile
}

D M Suci*, Supanti, Y Setiyantari, R Napitupulu, W Hermana

*Corresponding email:

dwi.margi2@gmail.com

Departemen Ilmu Nutrisi dan Teknologi Pakan, Fakultas Peternakan, Institut Pertanian Bogor (Bogor Agricultural University/IPB University)

\begin{abstract}
The aim of the study was to evaluated the effect of adding water hyacinth and fish oil in quail diet on performance, cholesterol and egg fatty acid profile. A total number of 200 unsex day old quail randomly assigned to 5 treatments and 4 replications that were reared for 5 weeks and then selected male or female. The results of sexing quail at week 5 were 95 females and 86 males. Growth period diets (0-5 weeks) contains $24 \%$ crude protein and metabolic energy of $2900 \mathrm{kcal}$ $\mathrm{kg}^{-1}$ and production period diets (5-12 weeks) contains $22 \%$ crude protein and $2900 \mathrm{kcal} \mathrm{kg}^{-1}$. The experimental design used a completely randomized design the level of water hyacinth and fish oil added were $0 \%, 1 \%, 2 \%, 3 \%, 4 \%$, and $0 \%, 4 \%, 5 \%, 6 \%, 7 \%$ respectively. The variables measured were quail performance (0-5 week age and 5-12 week age), cholesterol, and egg fatty acid profile. The results showed that addition of water hyacinth meal 1\% - $4 \%$ and fish oil $4 \%-5 \%$ in the diet had a higher feed consumption and body weight gain in growth periode compared to the control diet, with no difference on feed conversion ratio. There was no different effect on quail performance along production period in all treatments observed. Quail performance of the production period was not affected by all treatments. Unsaturated fatty acids tend to increased in quail eggs. The lowest cholesterol level of quail eggs was in the treatment of $2 \%$ of water hyacinth meal and $5 \%$ of fish oil in the diet. It was concluded that water hyacinth can be used as local feed ingredients in quail diet up to $4 \%$.
\end{abstract}

Key words: Coturnix coturnix japonica, egg cholesterol, egg fatty acid profile, performance, production

\section{ABSTRAK}

Penelitian ini bertujuan untuk mengevaluasi pengaruh pemberian eceng gondok (Eichornia crassipes) dan minyak ikan (Centrophorus atromarginatus) dalam ransum puyuh terhadap performa, kolesterol dan profil asam lemak telur. Penelitian ini menggunakan 200 ekor doq unsex dibagi ke dalam 5 perlakuan dan 4 ulangan yang dipelihara 5 minggu dan selanjutnya diseleksi jantan atau betina. Hasil seleksi pada minggu ke 5 terdapat 95 ekor betina dan 86 ekor jantan. Ransum puyuh periode pertumbuhan (0-5 minggu) mengandung protein $24 \%$ dan energi metabolis $2900 \mathrm{kkal} \mathrm{kg}^{-1}$ dan ransum untuk puyuh periode bertelur (5-12 minggu) mengandung protein $22 \%$ dan energi metabolis $2900 \mathrm{kkal} \mathrm{kg}^{-1}$. Rancangan percobaan yang digunakan adalah rancangan acak lengkap dengan perlakuan penggunaan eceng gondok yaitu $0 \%$ (kontrol), 1\%, 2\%, 3\%, dan $4 \%$ dengan minyak ikan hiu botol yaitu $0 \%, 4 \%, 5 \%, 6 \%$ dan 7 $\%$ di dalam ransum puyuh. Peubah yang diukur adalah performa puyuh (umur 0-5 minggu dan umur 5-12 minggu) dan komposisi kimia telur (profil asam lemak dan kadar kolesterol telur). Data dianalisis ragam dan jika terdapat perbedaan yang nyata diuji lagi dengan kontras orthogonal pada $\mathrm{p}<0,05$. Hasil penelitian menunjukkan bahwa pemberian tepung eceng gondok 1\%-4\% dan minyak ikan 4\%-5\% dalam ransum periode pertumbuhan menghasilkan konsumsi ransum dan pertambahan bobot badan lebih tinggi daripada ransum yang tidak menggunakan eceng gondok dan minyak ikan hiu tetapi menghasilkan konversi ransum yang sama. Performa puyuh periode produksi tidak dipengaruhi oleh perlakuan. Kadar asam lemak tidak jenuh cenderung meningkat pada telur puyuh. Kadar kolesterol telur puyuh paling rendah dengan pemberian $2 \%$ tepung eceng gondok dan $5 \%$ minyak ikan dalam ransum. Kesimpulan hasil penelitian bahwa eceng gondok dapat digunakan sebagai bahan pakan lokal pada ransum puyuh sampai $4 \%$.

Kata kunci: Coturnix coturnix japonica, kolesterol telur, performa, produksi, profil asam lemak telur 


\section{PENDAHULUAN}

Telur puyuh merupakan bahan pangan sumber protein selain telur ayam yang digemari oleh masyarakat yang mempunyai kadar nutrien berkualitas baik seperti kandungan protein, mineral, vitamin, asam amino, kolesterol dan asam lemak (Tunsaringkan et al. 2013; Tolik et al. 2014). Bobot telur puyuh paling kecil dibandingkan unggas lainnya sekitar 11,3 g (Tolik et al. 2014). Selain itu pemeliharaan puyuh mempunyai peluang ditingkatkan karena hanya membutuhkan waktu yang singkat untuk menghasilkan telur, sedikit ransum yang dikonsumsi, mempunyai daya tahan tubuh yang lebih baik dan mempunyai biaya pemeliharaan yang rendah (Hemid et al. 2010; Odo \& Nandi 2014; Mahmood et al. 2014). Konsumsi telur puyuh oleh masyarakat berpengaruh terhadap konsumsi bahan pangan bergizi yang dapat meningkatkan kesehatan. Informasi tentang kualitas telur puyuh seperti kandungan kolesterol dan asam lemak menjadi perhatian konsumen saat ini. Kadar kolesterol di dalam kuning telur puyuh lebih tinggi daripada kuning telur itik dan ayam (Aziz et al. 2012) sering menjadi perbincangan. Kadar asam lemak omega 3 tinggi yang seimbang dengan omega 6 dapat memberikan kelebihan pada telur puyuh yang diproduksi. Penelitian tentang asam lemak omega3 kuning telur puyuh juga sudah banyak diteliti (Tunsaringkarn et al. 2013; Guclu et al. 2008; Kamely et al. 2016). Penggunaan minyak di dalam ransum unggas sebagai sumber energi dan sebagai sumber asam lemak omega-3 banyak diteliti untuk meningkatkan kualitas telur puyuh. Minyak ikan mengandung asam lemak omega-3 lebih tinggi dibandingkan minyak nabati seperti sunflower oil, minyak jagung, minyak kedele (Kamely et al. 2016; Guclu et al. 2008)

Permasalahan bahan pakan yang digunakan untuk menyusun ransum yang baik dan murah tetapi menghasilkan performa yang baik dan bahan pangan fungsional merupakan suatu tujuan yang harus dicapai saat ini. Efisiensi antar input dan output yang tidak baik dapat menurunkan minat untuk mengembangkan telur puyuh sebagai bahan pangan yang murah. Eceng gondok mempunyai potensi yang baik sebagai bahan pakan pada unggas dilihat dari kandungan nutriennya (Riswandi, 2014; Sotolu \& Sule 2011; Malik et al. 2016; Saha et al., 2011, Mangisah et al. 2006). Eceng gondok memiliki sifat mudah tumbuh di perairan yang kondisinya subur dan cocok, selain itu eceng gondok dianggap sebagai tanaman yang dapat mendangkalkan danau atau waduk sehingga perlu dimanfaatkan seperti bahan pakan ternak. Kelemahan eceng gondok yang mempunyai kandungan energi yang rendah dapat dikombinasikan dengan minyak ikan sebagai sumber energi dan juga sumber asam lemak tidak jenuh. Minyak ikan banyak dijumpai pada pabrik pengolahan ikan. Minyak ikan banyak macamnya tergantung dari ikan yang diolah. Minyak ikan hiu botol merupakan salah satu minyak ikan hasil samping pengolahan ikan. Kombinasi yang tepat antara penggunaan eceng gondok yang mempunyai antioksidan dapat menurunkan oksidasi asam lemak tidak jenuh yang ada di minyak ikan diharapkan menghasilkan performa dan kualitas telur yang baik.

Penggunaan berbagai kombinasi ikan hiu botol dan eceng gondok perlu dilakukan percobaan untuk mendapatkan performa puyuh dan telur fungsional. Tujuan penelitian untuk mendapatkan kombinasi yang optimal penggunaan eceng gondok dan minyak ikan dalam ransum puyuh untuk menghasilkan performa, kolesterol dan profil asam lemak yang baik .

\section{METODE}

\section{Ternak dan Ransum Perlakuan}

Penelitian ini menggunakan 200 ekor doq unsex yang dipelihara pada periode starter dan grower (0-5 minggu) serta periode layer 5-12 minggu). Pada periode pertumbuhan, puyuh diacak dan dikelompokkan menjadi 5 perlakuan dan 4 ulangan dan setiap ulangan 10 ekor. Pada umur 5 minggu dilakukan sexing dan diperoleh 95 ekor betina dan 86 ekor jantan. Puyuh betina dipelihara selama 7 minggu. Puyuh diberi ransum perlakuan menggunakan tepung eceng gondok (TE) $1 \%$, $2 \%, 3 \%$ dan $4 \%$ yang dikombinasikan dengan minyak ikan hiu (MI) 4\%, 5\%, 6\% dan $7 \%$ dan ransum kontrol yang tidak menggunakan tepung eceng gondok dan minyak ikan hiu (Tabel 1 dan Tabel 2).

Tabel 1 Susunan dan komposisi nutrien ransum periode pertumbuhan (0-5 minggu)

\begin{tabular}{|c|c|c|c|c|c|}
\hline \multirow[t]{2}{*}{ Bahan pakan } & \multicolumn{5}{|c|}{ Perlakuan } \\
\hline & Kontrol & P1 & $\mathrm{P} 2$ & P3 & P4 \\
\hline Jagung kuning & 57 & 45 & 43 & 40 & 36 \\
\hline Bungkil kedelai & 29 & 26 & 26 & 27 & 29 \\
\hline Tepung ikan & 13 & 13 & 13 & 13 & 13 \\
\hline $\begin{array}{l}\text { Dedak gandum } \\
\text { kasar }\end{array}$ & 0 & 10 & 10 & 10 & 10 \\
\hline Eceng gondok & 0 & 1 & 2 & 3 & 4 \\
\hline Minyak ikan hiu & 0 & 4 & 5 & 6 & 7 \\
\hline $\mathrm{CaCO} 3$ & 0,5 & 0,5 & 0,5 & 0,5 & 0,5 \\
\hline Premik & 0,5 & 0,5 & 0,5 & 0,5 & 0,5 \\
\hline Total & 100 & 100 & 100 & 100 & 100 \\
\hline Suplemen Yeast & 1 & 1 & 1 & 1 & 1 \\
\hline \multicolumn{6}{|l|}{ Kandungan nutrien } \\
\hline $\begin{array}{l}\text { Energi metabolis } \\
\left(\mathrm{kkal} \mathrm{kg}^{-1}\right)\end{array}$ & 2922,80 & 2934,90 & 2965,40 & 2984,70 & 2992,80 \\
\hline Protein kasar (\%) & 24,76 & 24,04 & 24,04 & 24,39 & 25,10 \\
\hline Serat kasar (\%) & 3,38 & 4,01 & 4,13 & 4,29 & 4,50 \\
\hline Kalsium (\%) & 0,95 & 0,96 & 0,97 & 0,98 & 0,99 \\
\hline Fosfor (\%) & 0,49 & 0,51 & 0,51 & 0,52 & 0,53 \\
\hline Asam linoleat (\%) & 1,39 & 1,39 & 1,38 & 1,34 & 1,26 \\
\hline
\end{tabular}


Tabel 2 Susunan dan komposisi nutrien ransum periode pertumbuhan (5-12 minggu)

\begin{tabular}{|c|c|c|c|c|c|}
\hline \multirow[t]{2}{*}{ Bahan pakan } & \multicolumn{5}{|c|}{ Perlakuan } \\
\hline & Kontrol & P1 & P2 & P3 & P4 \\
\hline Jagung kuning & 63,9 & 48,9 & 46,9 & 44,8 & 42,8 \\
\hline Bungkil kedelai & 18 & 18 & 18 & 18 & 18 \\
\hline Tepung ikan & 13,3 & 13,3 & 13,3 & 13,3 & 13,3 \\
\hline $\begin{array}{l}\text { Dedak gandum } \\
\text { kasar }\end{array}$ & 0 & 10 & 10 & 10 & 10 \\
\hline Eceng gondok & 0 & 1 & 2 & 3 & 4 \\
\hline Minyak ikan hiu & 0 & 4 & 5 & 6 & 7 \\
\hline $\mathrm{CaCO} 3$ & 4,7 & 4,7 & 4,7 & 4,7 & 4,7 \\
\hline Premik & 0,1 & 0,1 & 0,1 & 0,1 & 0,1 \\
\hline Total & 100 & 100 & 100 & 100 & 100 \\
\hline Suplemen Yeast & 1 & 1 & 1 & 1 & 1 \\
\hline \multicolumn{6}{|l|}{ Kandungan nutrien } \\
\hline $\begin{array}{l}\text { Energi Metabolis } \\
\left(\text { kkal kg }^{-1)}\right.\end{array}$ & 2917,11 & 2882,61 & 2900,11 & 2914,26 & 2931,26 \\
\hline Protein kasar (\%) & 22,74 & 22,36 & 21,59 & 22,86 & 21,21 \\
\hline Serat kasar (\%) & 4,48 & 4,64 & 7,70 & 7,26 & 6,22 \\
\hline NDF (\%) & 15,07 & 19,48 & 20,09 & 19,52 & 19,76 \\
\hline ADF (\%) & 4,20 & 5,16 & 5,27 & 5,77 & 5,93 \\
\hline Hemiselulosa (\%) & 10,87 & 14,32 & 14,82 & 13,75 & 13,83 \\
\hline Selulosa (\%) & 3,07 & 3,73 & 5,27 & 4,14 & 4,27 \\
\hline Lignin (\%) & 0,88 & 1,66 & 1,55 & 1,57 & 1,29 \\
\hline Kalsium (\%) & 2,60 & 2,54 & 2,55 & 2,55 & 2,56 \\
\hline Fosfor (\%) & 0,48 & 0,48 & 0,48 & 0,49 & 0,49 \\
\hline Asam linoleat (\%) & 1,49 & 1,45 & 1,43 & 1,41 & 1,39 \\
\hline
\end{tabular}

Kandungan nutrien tepung eceng gondok terlihat pada Tabel 3 dan kandungan asam lemak ikan hiu botol terdapat pada Tabel 4. Eceng gondok terdiri dari daun, batang dan akar dipotong $\pm 5 \mathrm{~cm}$ kemudian dijemur dibawah sinar matahari sampai kering, digiling menjadi tepung. Ransum perlakuan berbentuk crumble terdiri dari ransum periode pertumbuhan yang mengandung protein 24\% dan energi metabolis $2900 \mathrm{kkal} \mathrm{kg}^{-1}$. Ransum periode produksi (5-12 minggu) mengandung protein $22 \%$ dan energi metabolis $2900 \mathrm{kkal} \mathrm{kg}^{-1}$.

Tabel 3 Komposisi kimia tepung eceng gondok

\begin{tabular}{lc}
\hline Komponen & Kadar \\
\hline Bahan kering (\%) & 87,27 \\
Protein kasar (\%) & 13,25 \\
Serat kasar (\%) & 24,99 \\
Lemak kasar (\%) & 0,57 \\
BETN (\%) & 34,77 \\
Abu (\%) & 13,69 \\
NDF (\%) & 72,63 \\
ADF (\%) & 39,40 \\
Hemiselulosa (\%) & 33,23 \\
Selulosa (\%) & 32,43 \\
Lignin (\%) & 4,70 \\
Silika (\%) & 2,26 \\
Energi bruto (kkal kg-1) & 3534 \\
\hline
\end{tabular}

Hasil analisis Laboratorium Ilmu dan Teknologi Pakan, Departemen Ilmu Nutrisi dan Teknologi Pakan, Fakultas Peternakan IPB

\section{Prosedur Penelitian}

Pemeliharaan puyuh menggunakan kandang dengan ukuran $0,5 \mathrm{~m} \times 0,5 \mathrm{~m} \times 0,5 \mathrm{~m}$ berisi 20 petak yang dilengkapi tempat pakan dan air minum. Pemberian pakan dan air minum ad libitum. Vitachick digunakan melalui air minum untuk mencegah stres dan dilakukan vaksinasi ND pada umur 3 dan 21 hari. Setiap minggu dilakukan penimbangan bobot badan dan jumlah pakan yang diberikan ke puyuh. Data konsumsi ransum dan bobot badan pada umur puyuh 0-5 minggu diukur setiap minggu. Konversi ransum dihitung dari konsumsi ransum dibagi pertambahan bobot badan untuk periode pertumbuhan 0-5 minggu. Pada puyuh periode produksi diukur konsumsi ransum, produksi telur, konversi ransum, boot telur, warna kuning telur dan kadar kolesterol dan asam lemaktelur puyuh. Pencatatan dan penimbangan bobot telur dilakukan setiap hari. Produksi telur dihitung berdasarkan quail day production yaitu produksi telur dibagi dengan massa telur dihitung per minggu. Sampel telur dikomposit terdiri dari putih dan kuning telur dan dianalisis kandungan kolesterol dan asam lemak.

\section{Rancangan Percobaan dan Analisis Statistik}

Rancangan Acak lengkap digunakan pada penelitian ini terdiri dari 5 perlakuan dan 4 ulangan. Data yang diperoleh dianalisis ragam bila terdapat perbedaan dilanjutkan dengan uji kontras orthogonal pada $\mathrm{P}<0,05$. Perlakuan yang diuji pada penelitian adalah penggunaan eceng gondok yaitu $0 \%$ (kontrol), $1 \%, 2 \%, 3 \%$, dan $4 \%$ dengan minyak ikan hiu botol yaitu $0 \%, 4 \%, 5 \%, 6 \%$ dan $7 \%$ di dalam ransum puyuh. Peubah yang diukur adalah performa puyuh pada periode pertumbuhan dan periode produksi. Selain itu diukur juga kadar kolesterol dan profil asam lemak telur.

\section{Pengukuran Peubah}

Konsumsi Ransum (g ekor-1 minggu-1) diukur dengan mengurangi pemberian ransum dengan sisa ransum setiap akhir minggu.

Pertambahan Bobot Badan (g ekor ${ }^{-1}$ minggu $^{-1}$ ) diukur dengan mengurangi bobot badan puyuh pada akhir minggu dengan bobot badan awal minggu.

Konversi Ransum dihitung dengan membagi konsumsi ransum dengan pertambahan bobot badan untuk puyuh periode pertumbuhan dan membagi konsumsi ransum dengan bobot telur total yang diperoleh untuk puyuh periode produksi telur.

Quail Day Production (\%) dihitung membagi produksi telur setiap minggu dengan jumlah puyuh yang ada dikalikan seratus.

Kadar Kolesterol Telur (mg g-1) dan Profil Asam Lemak $\left(\mathrm{mg} \mathrm{g}^{-1}\right)$ dianalisis dari sampel komposit setiap ulangan. Sampel terdiri dari campuran putih telur dan kuning telur. 
Analisis Kolesterol Telur diukur berdasarkan metode Libermann-Buchard. Cara kerjanya adalah sampel ditimbang sebanyak 0,2 g dan dimasukkan ke dalam tabung sentrifuse berskala 15. Kemudian ditambahkan cairan alkohol eter 3:1 sebanyak $12 \mathrm{ml}$, diaduk hingga homogen. Larutan didiamkan sambil dikocok satu sampai dua kali selama 30 menit. Pengaduk dibilas dengan menggunakan alkohol eter 3:1 dan disetarakan menjadi 15 ml, lalu disentrifus dengan kecepatan 3000 rpm selama 15 menit. Supernatan dipindahkan ke dalam gelas piala $50 \mathrm{ml}$ dan dipanaskan pada penangas air sampai kering. Ekstrak residu dilarutkan dengan 2,5 ml kloroform sedikit demi sedikit atau dicuci sebanyak dua kali dan dimasukkan ke dalam tabung reaksi $10 \mathrm{ml}$ untuk disetarakan volumenya menjadi $5 \mathrm{ml}$. Selanjutnya kolesterol standar $5 \mathrm{ml}$ (0,4 mg kolesterol dalam $5 \mathrm{ml}$ klorofrom) dimasukkan ke dalam tabung reaksi yang lain. Keduanya ditambahkan $2 \mathrm{ml}$ asetat anhidrida dan $100 \mu \mathrm{l} \mathrm{H} 2 \mathrm{SO} 4$ pekat, kemudian dikocok sampai timbul warna hijau, lalu disimpan selama 15 menit di dalam ruang gelap. Selanjutnya dilakukan pembacaan dengan menggunakan spektrofotometer pada panjang gelombang $420 \mathrm{~nm}$. Nilai kolesterol tersebut diperoleh dari perhitungan dengan menggunakan persamaan kurva standar kolesterol sebagai berikut:

Kadar Kolesterol(mg 100 $\mathrm{mg}^{-1}$ )

$$
=[(0,214 \times \text { Absorbansi Sampel })+0,005]: \frac{\text { Bobot sampel }}{10}
$$

Analisis Asam Lemak Telur. Prosedur analisis yang dilakukan adalah sampel ditimbang kira-kira 0,5 g kemudian ditambahkan $\mathrm{NaOH}$ 0,5 N sebanyak $5 \mathrm{ml}$, setelah itu dipanaskan dalam waterbath pada suhu $80^{\circ} \mathrm{C}$ selama 20 menit. Kemudian diangkat dan dibiarkan dingin. Setelah itu, ditambahkan BF3 sebanyak $5 \mathrm{ml}$, dipanaskan kembali dalam waterbath pada suhu $80^{\circ} \mathrm{C}$ selama 20 menit. Kemudian didinginkan pada suhu kamar dan ditambahkan $\mathrm{NaCl}$ jenuh sebanyak $2 \mathrm{ml}$. Selanjutnya ditambahkan n-HEXAN $2 \mathrm{ml}$, lalu dikocok dan didiamkan. Setelah itu, diambil fase atas (lapisan nHEXAN), kemudian larutan siap untuk diinjekkan ke alat GC.

\section{HASIL DAN PEMBAHASAN}

\section{Performa Puyuh Periode Pertumbuhan (0-5 minggu)}

Performa puyuh yang diberi pakan berbagai level kombinasi tepung eceng gondok dan minyak ikan pada puyuh periode pertumbuhan terlihat pada Tabel 5 . Konsumsi ransum dan pertambahan bobot badan nyata meningkat $(\mathrm{p}<0,05)$ tetapi konversi ransum tidak berbeda dengan perlakuan kontrol (tanpa eceng gondok dan tepung ikan). Konsumsi ransum yang meningkat menunjukkan palatabilitas ransum lebih baik dan tidak dipengaruhi keambaan ransum karena penggunaan tepung eceng gondok. Tepung eceng gondok mempunyai sifat amba (bulky) yang tinggi karena mengandung serat kasar tinggi yaitu 24,9\% (Tabel 3) diperkuat oleh Malik et al. (2016). Menurut Adeyemi et al. (2012) terdapat kecenderungan konsumsi ransum meningkat berhubungan dengan meningkatnya keambaan ransum. Keambaan ransum karena tingginya serat kasar akan mengandung konsentrasi nutrien rendah per unit volume dan unggas akan makan lebih banyak untuk memenuhi kebutuhan nutriennya (Adeyemi et al. (2012). Pada penelitian ini, keambaan ransum karena penggunaan tepung eceng gondok dapat diturunkan dengan penggunaan minyak ikan hiu 4\%-7\% dan ransum yang dibuat bentuk crumble.

Penggunaan tepung eceng gondok 1\%-4\% dalam ransum puyuh menghasilkan ransum yang rendah serat kasarnya (3\%-4\%) sehingga tidak menimbulkan permasalahan di dalam pencernaan dan penyerapan nutrien dari ransum terlihat dari meningkatkan pertambahan bobot badan walaupun kecernaan eceng gondok rendah (Riswandi, 2014). Selain itu adanya kandungan zat anti nutrien dalam tepung eceng gondok masih dapat ditolerir oleh puyuh periode pertumbuhan. Menurut Aziz et al. (2012) tepung eceng gondok

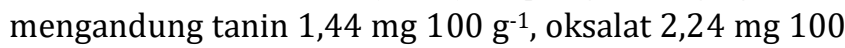
$\mathrm{g}^{-1}$, saponin $0,26 \mathrm{mg} 100 \mathrm{~g}^{-1}$, fitat $0,27 \mathrm{mg} 100 \mathrm{~g}^{-1}$ dan alkaloid 0,01 mg $100 \mathrm{~g}^{-1}$. Kadar serat kasar eceng gondok yang tinggi menyebabkan kadar energi metabolis eceng gondok rendah yaitu sekitar $1900 \mathrm{kkal} \mathrm{kg}^{-1}$ (Malik et al. 2016) sehingga perlu ditambahkan sumber energi lain yaitu minyak ikan yang digunakan dalam ransum sebanyak 4\%-7\%. Pengaruh dari penggunan minyak ikan yang tinggi (sampai $7 \%$ dalam ransum) akan menurunkan energi metabolis yang dihasilkan dari kandungan lemak ransum. Leeson dan Summers (2008) menyatakan kadar lemak ransum lebih dari 5\% menghasilkan energi metabolis $94 \%$. Ransum perlakuan pada penelitian ini tidak mengganggu konversi ransum seperti terlihat pada penelitian Rusmana (2007) yaitu penggunaan minyak lemuru pada ayam broiler pada level 6\% menghasilkan konversi ransum paling efisien dibandingkan tanpa minyak ikan

Tabel 5 Performa puyuh (Coturnix coturnix japonica) umur 0-5 minggu

\begin{tabular}{|c|c|c|c|c|c|}
\hline \multirow[t]{2}{*}{ Peubah } & \multirow[t]{2}{*}{ Kontrol } & \multicolumn{4}{|c|}{ Pemberian } \\
\hline & & $\mathrm{P} 1$ & $\mathrm{P} 2$ & P3 & $\mathrm{P} 4$ \\
\hline Konsumsi ransum & $59,55 \pm$ & $67,03 \pm$ & $61,61 \pm$ & $67,57 \pm$ & $67,39 \pm$ \\
\hline$\left(\right.$ g ekor $^{-1}$ minggu $\left.^{-1}\right)$ & $6,11^{\mathrm{a}}$ & $3,61^{b}$ & $4,90^{\mathrm{a}}$ & $7,83^{b}$ & $10,68^{b}$ \\
\hline Pertambahan & $16,73 \pm$ & $19,41 \pm$ & $17,86 \pm$ & $17,87 \pm$ & $18,90 \pm$ \\
\hline $\begin{array}{l}\text { bobot badan (g } \\
\text { ekor }^{-1} \text { minggu }^{-1} \text { ) }\end{array}$ & $1,43^{a}$ & $1.41^{c}$ & $0,96^{\mathrm{b}}$ & $0,82^{b}$ & $1,47^{c}$ \\
\hline $\begin{array}{l}\text { Konversi } \\
\text { ransum }\end{array}$ & $\begin{array}{c}3,48 \pm 0 \\
52\end{array}$ & $\begin{array}{c}3,56 \pm 0 \\
42\end{array}$ & $\begin{array}{c}3,37 \pm 0 \\
24\end{array}$ & $\begin{array}{c}3,71 \pm 0 \\
47\end{array}$ & $\begin{array}{c}3,46 \pm 0 \\
33\end{array}$ \\
\hline
\end{tabular}

P1=1\% TE, 4 \% MI; P2=2 \% TE, 5 \%MI; P3=3\% TE, 6 \% MI; P4= 4 \% TE, $7 \% \mathrm{MI}$; Superskrip berbeda pada baris yang sama menunjukkan perbedaan nyata $(\mathrm{p}<0,05)$ 
Tabel 6 Rataan konsumsi ransum (g ekor-1 minggu $^{-1}$ ) selama 7 minggu

\begin{tabular}{lccccc}
\hline \multirow{2}{*}{$\begin{array}{l}\text { Umur } \\
\text { puyuh } \\
\text { (Minggu) }\end{array}$} & Kontrol & \multicolumn{5}{c}{ Perlakuan } \\
\cline { 3 - 6 } & & $\mathrm{P} 1$ & $\mathrm{P} 2$ & $\mathrm{P} 3$ & $\mathrm{P} 4$ \\
\hline 6 & $94,73 \pm$ & $120,11 \pm$ & $106,65 \pm$ & $129,01 \pm$ & $116,41 \pm$ \\
& 27,20 & 2,12 & 27,88 & 25,51 & 7,95 \\
7 & $125,22 \pm$ & 129,20 & $120,41 \pm$ & $123,87 \pm$ & $125,16 \pm$ \\
& 14,38 & $\pm 11,16$ & 0,58 & 6,43 & 6,05 \\
8 & $121,73 \pm$ & $129,57 \pm$ & $136,14 \pm$ & $126,16 \pm$ & $124,47 \pm$ \\
& 8,46 & 2,18 & 9,61 & 34,85 & 13,91 \\
9 & $124,56 \pm$ & $147,03 \pm$ & $157,09 \pm$ & $162,76 \pm$ & $144,42 \pm$ \\
& 34,75 & 34,15 & 20,23 & 29,28 & 35,35 \\
10 & $158,51 \pm$ & 178,18 & $160,82 \pm$ & $148,97 \pm$ & $135,08 \pm$ \\
& 16,32 & $\pm 11,46$ & 14,79 & 30,99 & 14,35 \\
11 & $135,44 \pm$ & $163,08 \pm$ & $146,93 \pm$ & $136,10 \pm$ & $134,32 \pm$ \\
& 4,55 & 21,47 & 10,27 & 17,08 & 8,36 \\
12 & $137,28 \pm$ & $134,48 \pm$ & $136,91 \pm$ & $123,03 \pm$ & $140,18 \pm$ \\
& 3,67 & 5,16 & 24,45 & 11,67 & 22,64 \\
\hline Total & 894,09 & 1001,65 & 964,95 & 949,9 & 920,04 \\
\hline Rataan & $128,21 \pm$ & $143,09 \pm$ & $137,85 \pm$ & $135,70 \pm$ & $131,43 \pm$ \\
& 15,62 & 12,53 & 15,40 & 22,26 & 15,52 \\
\hline
\end{tabular}

P1=1\% TE, 4 \% MI; P2=2 \% TE, 5 \%MI; P3=3\% TE, 6 \% MI; P4= 4 \% TE, $7 \% \mathrm{MI}$

\section{Performa Puyuh Periode Produksi (6-12 minggu)}

Performa puyuh periode produksi telur dengan pemberian kombinasi tepung eceng gondok dengan minyak ikan hiu terlihat pada Tabel 6, Tabel 7, Tabel 8 dan Tabel 9. Rataan konsumsi ransum, produksi telur, konversi ransum dan bobot telur tidak dipengaruhi oleh pemberian kombinasi tepung eceng gondok dan minyak ikan hiu. Konsumsi ransum per minggu berkisar 18-20 g ekor $^{-1}$ sesuai dengan hasil penelitian Hilmi et al. (2011) dan Khairani et al. (2011). Puyuh diberi perlakuan selama 7 minggu diperoleh rataan quail day production berkisar 55,75 - 66,92\% dengan bobot telur berkisar 8,9 g - 9,11 g butir ${ }^{-1}$.

Kadar serat kasar ransum puyuh periode produksi sampai 7,7\% (Tabel 2) tidak menurunkan konsumsi ransum (Tabel 6) karena ransum berbentuk crumble.

Tabel 7 Rataan quail day production (\%) selama 7 minggu

\begin{tabular}{lrrrrr}
\hline $\begin{array}{l}\text { Umur } \\
\text { puyuh } \\
\text { (Minggu) }\end{array}$ & Kontrol & \multicolumn{4}{c}{ Perlakuan } \\
\cline { 3 - 6 } 6 & & $\mathrm{P} 1$ & $\mathrm{P} 2$ & $\mathrm{P} 3$ & $\mathrm{P} 4$ \\
\hline 6 & & $3,75 \pm$ & 0 & $0,89 \pm$ & $0,45 \pm$ \\
& & 3,57 & & 1,79 & 0,90 \\
& $20,71 \pm$ & $35,71 \pm$ & $20,24 \pm$ & $30,18 \pm$ & $24,59 \pm$ \\
& 11,53 & 10,03 & 16,33 & 25,59 & 8,17 \\
8 & $48,22 \pm$ & $71,07 \pm$ & $54,46 \pm$ & $68,16 \pm$ & $60,34 \pm$ \\
& 22,08 & 19,39 & 16,34 & 23,28 & 13,04 \\
9 & $78,57 \pm$ & $77,57 \pm$ & $77,57 \pm$ & $72,62 \pm$ & $77,82 \pm$ \\
& 18,45 & 12,45 & 22,86 & 20,34 & 8,24 \\
10 & $87,80 \pm$ & $91,43 \pm$ & $75,30 \pm$ & $74,88 \pm$ & 79,62 \\
& 11,43 & 10,94 & 16,59 & 15,82 & $\pm 12,14$ \\
11 & $86,01 \pm$ & $93,22 \pm$ & $83,33 \pm$ & $71,25 \pm$ & $82,52 \pm$ \\
& 8,27 & 5,88 & 15,53 & 14,31 & 2,61 \\
12 & $91,79 \pm$ & $95,72 \pm$ & $80,89 \pm$ & $72,26 \pm$ & 81,60 \\
& 5,49 & 5,47 & 5,63 & 22,70 & $\pm 15,22$ \\
\hline Rataan & $59,01 \pm$ & $66,92 \pm$ & $55,89 \pm$ & $55,75 \pm$ & $58,33 \pm$ \\
& 11,02 & 18,92 & 13,33 & 17,69 & 8,62 \\
\hline
\end{tabular}

Tabel 8 Rataan konversi ransum selama 6 minggu

\begin{tabular}{lrrrrr}
\hline \multirow{2}{*}{$\begin{array}{l}\text { Umur } \\
\text { puyuh } \\
\text { (Minggu) }\end{array}$} & Kontrol & \multicolumn{4}{c}{ Perlakuan } \\
\cline { 3 - 6 } & & $\mathrm{P} 1$ & $\mathrm{P} 1$ & $\mathrm{P} 1$ & $\mathrm{P} 1$ \\
\hline 7 & $1,96 \pm$ & $2,12 \pm$ & $1,99 \pm$ & $2,02 \pm$ & $2,15 \pm$ \\
& 0,26 & 0,20 & 0,2 & 0,29 & 0,08 \\
8 & 1.86 & $2,01 \pm$ & $2,21 \pm$ & $2,30 \pm$ & $1,93 \pm$ \\
& \pm 0.15 & 0,11 & 0,25 & 0,47 & 0,30 \\
9 & $2,23 \pm$ & $2,70 \pm$ & $2,48 \pm$ & $2,63 \pm$ & $2,79 \pm$ \\
& 0,67 & 0,41 & 0,45 & 0,37 & 0,52 \\
10 & $2,42 \pm$ & $2,54 \pm$ & $2,61 \pm$ & $2,25 \pm$ & $2,20 \pm$ \\
& 0,21 & 0,25 & 0,41 & 0,49 & 0,23 \\
11 & $2,21 \pm$ & $2,29 \pm$ & $2,34 \pm$ & $2,05 \pm$ & $2,19 \pm$ \\
& 0,14 & 0,40 & 0,27 & 0,27 & 0,08 \\
& $2,15 \pm$ & $2,16 \pm$ & $2,16 \pm$ & $1,99 \pm$ & $2,01 \pm$ \\
12 & 0,19 & 0,25 & 0,37 & 0,16 & 0,47 \\
\hline Rataan & $2,14 \pm$ & $2,30 \pm$ & $2,29 \pm$ & $2,21 \pm$ & $2,21 \pm$ \\
& 0,27 & 0,27 & 0,33 & 0,34 & 0,28 \\
\hline
\end{tabular}

Perlakuan konsumsi ransum yang tidak berbeda nyata menghasilkan konsumsi nutrien yang masuk ke dalam tubuh juga sama (ransum iso protein dan iso energi) menyebabkan produksi telur, konversi ransum dan bobot telur tidak berbeda nyata. Selain itu unggas dewasa mempunyai kemampuan mencerna serat kasar lebih tinggi daripada puyuh muda. Kemampuan unggas mencerna serat kasar tergantung perubahan ukuran usus. Menurut Savory \& Gentle (1976) ukuran usus lebih besar pada unggas yang diberi makan makanan berserat tinggi. Kandungan energi ransum pada penelitian ini dipengaruhi oleh energi metabolis dari tepung eceng gondok dan minyak ikan hiu. Kandungan energi eceng gondok rendah sekitar $1900 \mathrm{kkal} \mathrm{kg}^{-1}$ (Malik et al. 2016) dapat diimbangi dengan kandungan energi metabolis minyak ikan hiu sekitar 6000-8000 kkal kg-1 (NRC 1994).

\section{Profil Asam Lemak Telur}

Umumnya penggunaan minyak ikan pada ransum dapat sebagai sumber energi dan sumber asam lemak esensial, meningkatkan penyerapan vitamin yang larut lemak dan meningkatkan palatabilitas. Profil asam lemak telur

Tabel 9 Rataan bobot telur (g butir-1) selama 7 minggu

\begin{tabular}{lrrrrr}
\hline $\begin{array}{l}\text { Umur } \\
\text { puyuh } \\
\text { (Minggu) }\end{array}$ & Kontrol & \multicolumn{5}{c}{ Perlakuan } \\
\cline { 3 - 6 } 6 & & $\mathrm{P} 1$ & $\mathrm{P} 2$ & $\mathrm{P} 3$ & $\mathrm{P} 4$ \\
\hline 6 & & $7,76 \pm$ & 0 & $7,40 \pm 0$ & $7,55 \pm 0$ \\
& $9,09 \pm$ & $8,77 \pm$ & $8,67 \pm$ & $9,14 \pm$ & $8,41 \pm$ \\
& 0,36 & 0,55 & 0,52 & 0,64 & 0,25 \\
8 & $9,25 \pm$ & $9,25 \pm$ & $8,82 \pm$ & $9,37 \pm$ & $9,14 \pm$ \\
& 0,53 & 0,46 & 0,54 & 0,25 & 0,53 \\
9 & $8,99 \pm$ & $9,31 \pm$ & $8,90 \pm$ & $9,55 \pm$ & $8,96 \pm$ \\
& 0,38 & 0,42 & 0,74 & 0,32 & 0,21 \\
10 & $8,86 \pm$ & $9,38 \pm$ & $8,90 \pm$ & $9,48 \pm$ & $8,81 \pm$ \\
& 0,31 & 0,39 & 0,71 & 0,11 & 0,31 \\
11 & $8,72 \pm$ & $9,18 \pm$ & $9,03 \pm$ & $9,31 \pm$ & $9,04 \pm$ \\
& 0,36 & 0,43 & 0,53 & 0,27 & 0,28 \\
12 & $9,18 \pm$ & $9,15 \pm$ & $8,82 \pm$ & $9,54 \pm$ & $9,07 \pm$ \\
& 0,51 & 0,43 & 0,44 & 0,17 & 0,26 \\
\hline Rataan & $9,01 \pm 0,41$ & $8,97 \pm$ & $8,86 \pm$ & $9,11 \pm$ & $8,71 \pm$ \\
& & 0,44 & 0,58 & 0,29 & 0,31 \\
\hline
\end{tabular}


Tabel 10 Profil asam lemak (mg $\mathrm{g}^{-1}$ ) dan kadar kolesterol $\left(\mathrm{mg} \mathrm{g}^{-1}\right)$ telur puyuh*

\begin{tabular}{|c|c|c|c|c|c|}
\hline \multirow{3}{*}{ Peubah } & \multirow{2}{*}{ Kontrol } & \multicolumn{4}{|c|}{ Perlakuan } \\
\hline & & $\mathrm{P} 1$ & P2 & P3 & P4 \\
\hline & \multicolumn{5}{|c|}{ Mg g } \\
\hline \multicolumn{6}{|c|}{ Asam Lemak Jenuh } \\
\hline $\begin{array}{l}\text { Kaprilat } \\
\text { (C8: 0) }\end{array}$ & 0,49 & 0,55 & 0,53 & 0,50 & 0,57 \\
\hline $\begin{array}{l}\text { Laurat } \\
\text { (C12:0) }\end{array}$ & 0,36 & 0,39 & 0,36 & 0,34 & 0,39 \\
\hline Miristat & 0,000 & 0,001 & 0,000 & 0,000 & 0,000 \\
\hline (C14:0) & 76 & 50 & 58 & 63 & 66 \\
\hline $\begin{array}{l}\text { Palmitat } \\
\text { (C16:0) }\end{array}$ & 2,29 & 2,04 & 2,03 & 2,00 & 2,03 \\
\hline Stearat & 0,000 & 0,001 & 0,000 & 0,000 & 0,000 \\
\hline (C18:0) & 90 & 15 & 86 & 93 & 96 \\
\hline Total & 3,14 & 2,98 & 2,92 & 2,84 & 2,99 \\
\hline \multicolumn{6}{|c|}{ Asam lemak tidak jenuh } \\
\hline $\begin{array}{l}\text { Oleat } \\
\text { (C18:1) }\end{array}$ & 0,67 & 0,75 & 0,80 & 0,82 & 0,77 \\
\hline Linoleat & 0,000 & 0,000 & 0,000 & 0,000 & 0,000 \\
\hline (C18:2) & 14 & 15 & 17 & 23 & 15 \\
\hline $\begin{array}{l}\text { Linolenat } \\
\text { (C18:3) }\end{array}$ & 0,30 & 0,34 & 0,39 & 0,40 & 0,38 \\
\hline $\begin{array}{l}\text { Arakhidonat } \\
\text { (C20:4) }\end{array}$ & 0,03 & 0,09 & 0,11 & 0,11 & 0,11 \\
\hline EPA & 0,25 & 0,27 & 0,28 & 0,29 & 0,32 \\
\hline $\begin{array}{l}\text { Eikosapentan } \\
\text { oat (C22:5) }\end{array}$ & & & & & \\
\hline $\begin{array}{l}\text { Dokosahexae } \\
\text { noat (C22:6) }\end{array}$ & 0,09 & 0,09 & 0,11 & 0,11 & 0,12 \\
\hline Total & 1,05 & 1,55 & 1,69 & 1,73 & 1,69 \\
\hline Kholesterol & 20,10 & 19,84 & 19,14 & 19,99 & 19,74 \\
\hline
\end{tabular}

puyuh (Tabel 10) terlihat asam palmitat merupakan asam lemak jenuh yang dominan dan asam oleat merupakan asam lemak tidak jenuh yang paling tinggi pada telur puyuh sesuai dengan Grigorova et al. (2004) dan Guclu et al. (2008). Kadar asam lemak jenuh cenderung menurun dan asam lemak tidak jenuh cenderung meningkat dengan penggunaan tepung eceng gondok dan minyak ikan hiu yang semakin meningkat. Kandungan asam lemak $\alpha$-linolenat (C18:3) telur puyuh hasil penelitian berkisar dari $0,3 \mu \mathrm{g} \mathrm{ml}^{-1}-0,4 \mathrm{mg} \mathrm{g}^{-1}$ telur sedangkan DHA berkisar dari 0,092 $\mu \mathrm{g} \mathrm{ml}^{-1}-0,115 \mathrm{mg} \mathrm{g}$ 1 telur. EPA berkisar dari 0,253 $\mu \mathrm{g} \mathrm{ml}^{-1}-0,293 \mathrm{mg} \mathrm{g}^{-1}$ telur.

Rendahnya kandungan asam lemak tidak jenuh terutama linoleat dan linolenat dipengaruhi oleh kualitas minyak ikan yang digunakan. Kadar minyak ikan hiu botol yang digunakan penelitian ini mengandung rendah asam linoleat $\left(0,44 \mathrm{mg} \mathrm{g}^{-1}\right)$ dan linolenat $\left(0,0006 \mathrm{mg} \mathrm{g}^{-1}\right)$ jika dibandingkan dengan minyak ikan menurut Guclu et al. (2008). Penggunaan minyak lemuru $4 \%$ dalam ransum ayam berpengaruh nyata $(\mathrm{p}<0,05)$ meningkatkan asam lemak omega 3 dan turunannya (EPA dan DHA) dalam kuning telur jika dibandingkan penggunaan minyak kelapa sawit dalam ransum (Sastrodihardja et al. 1998). Minyak ikan yang diproduksi di Indonesia (Surabaya, Sorong, Garut dan Muncar) mengandung asam lemak yang sangat bervariasi yaitu kadar SFA 0,03\% - 38,15\%, MUFA 0,04\% - 32,18\%, untuk kadar PUFA minyak ikan dari Sorong sebesar 0,26\% dan dari Muncar 28,44\% (Maulana et al. 2014). Sumber asam lemak juga diperoleh dari jagung kuning, tepung ikan dan bungkil kedelai yang mengandung minyak (Gucluet al. 2008). Kandungan asam lemak tidak jenuh minyak ikan hiu botol yang digunakan pada penelitian mengandung asam lemak EPA $0,117 \mathrm{mg} \mathrm{g}^{-1}$ dan DHA 0,328 $\mathrm{mg} \mathrm{g}^{-1}$ lebih rendah dari kandungan EPA (59 $\left.\mathrm{g} \mathrm{kg}^{-1}\right)$ dan DHA (150 $\left.\mathrm{g} \mathrm{kg}^{-1}\right)$ minyak ikan yang digunakan oleh Kamely et al. (2016) dan Guclu et al. (2008). Kandungan asam lemak ikan dipengaruhi oleh jenis ikan dan jenis pengolahan (Damongilala 2008) yaitu ekstraksi pembuatan minyak hati ikan cucut botol dengan pengeringan oven dan matahari mempengaruhi kadar asam lemak tidak jenuh.

\section{Kadar Kolesterol Telur}

Kadar kolesterol telur puyuh cenderung menurun dengan penggunaan tepung eceng gondok dibandingkan kontrol (Tabel 10). Hal ini seiring dengan cenderung menurunnya kadar asam lemak jenuh ransum (Tabel 10) karena semakin meningkatnya kandungan serat kasar ransum (Tabel 2). Kadar koolesterol telur puyuh paling rendah dengan pemberian $2 \%$ tepung eceng gondok dan $5 \%$ minyak ikan hiu dalam ransum. Kecenderungan penurunan kolesterol pada telur puyuh yang diberi eceng gondok disebabkan oleh adanya zat anti nutrien saponin pada eceng gondok dan kadar serat kasar ransum yang lebih tinggi 6\%-7\% (Tabel 2). Mona et al. (2013) menyatakan bahwa peningkatan serat kasar ransum dari 3\%-6\% nyata menurunkan kadar kolesterol telur ayam. Selain itu eceng gondok mempunyai potensi sebagai antioksidan ( IC50) berkisar $97,0 \mu \mathrm{g} \mathrm{ml}^{-1} \pm 5,4$ $\mu \mathrm{g} \mathrm{ml}^{-1}$ dan $97,4 \mu \mathrm{g} \mathrm{ml}^{-1} \pm 2,7 \mu \mathrm{g} \mathrm{ml}^{-1}$ ) (Aboul-Enein et al. 2011). Phenolic dan flavonoid pada eceng gondok mempunyai aktivitas antioksidan flavonoid dapat menurunkan kolesterol dengan menghambat aktivitas enzim 3-hidroksi 3-metil-glutaril-CoA yang menyebabkan penghambatan sintesis kolesterol (Metwally \& Sawaisi 2009). Saponin dapat menurunkan kadar kolesterol dengan mekanisme kerja mengikat asam empedu sehingga dapat menurunkan sirkulasi asam empedu dan meningkatkan eksresi kolesterol (Metwally \& Sawaisi 2009; Sim et al. 1984). Saponin berpotensi menurunkan kolesterol pada kuning telur dan meningkatkan produksi dan kualitas telur (Afrose et al. 2010). Aziz et al. (2012) menyatakan bahwa kadar saponin pada eceng gondok hanya 0,26 mg $100 \mathrm{~g}^{-1}$ 
sehingga belum mempunyai peranan besar nyata menurunkan kolesterol telur pada level penggunaan eceng gondok sampai $4 \%$ dalam ransum.

\section{SIMPULAN}

Penggunaan tepung eceng gondok $1 \%-4 \%$ dan minyak ikan $4 \%-7 \%$ dalam ransum puyuh periode pertumbuhan meningkatkan konsumsi ransum dan pertambahan bobot badan, tetapi tidak berpengaruh terhadap performa puyuh pada periode produksi telur. Asam lemak tidak jenuh cenderung meningkat pada telur puyuh dan kadar kolesterol telur puyuh paling rendah dengan pemberian $2 \%$ tepung eceng gondok dan $5 \%$ minyak ikan dalam ransum.

\section{DAFTAR PUSTAKA}

Aboul-Enein AM, Al-Abd A, Shalaby EA, Abul-Ela F, Nasr-Allah AA \& Mahmoud AM. 2011. Eichornia crassipes (MarT) solm. Plant Signal Behaviour. 6(6): 834-836

Afrose S, Hossain MS \& Tsuji H. 2010. Effect of dietary karaya saponin on serum and egg yolk cholesterol in laying hens. British Poultry Science. 51 (6) : 797-804

Adeyemi OA, Adekoya JA \& Abayomi R. 2012. Performance of broiler chickens fed diets containing cassave leaf: blood meal mix as replacement for soybean meal. Revista Cientifica UDO Agricola. 12 (1): 212-219

Aziz Z, Cyriac S, Beena V \& Philomina PT. 2012.Comparison of cholesterol content in chicken, duck and quail eggs. Journal Veterinary Animal Science. 43: 64-66

Bragagnolo N \& Rodriguez-Amaya DB. 2003. Comparison of the cholesterol content of Brazilian chicken and quail eggs. Journal of food Composition and Analysis. 16(2): 147-153

Chimote MJ, Barmase BS, Raut AS, Dhok AP \& Kuralkar SV.2009. Effect of supplementation of probiotic and enzymes on performance of Japanese quails. Veterinary World. 2 (6): 219-220

Damongilala LJ. 2008. Kandungan asam lemak tak jenuh minyak hati ikan cucut botol (Cenctrophorus sp) yang diekstraksi dengan cara pemanasan. Jurnal Ilmiah Sains. 8(2): 249-253

Grigorova S, Nikolova M, Penkov D \& Gerzilov V. 2014. Egg yolk lipid change in Japanese given Tribulus terrestris extract. Bulgarian Journal of Agricultural Science. 20 (6) : 1472-1476

Guclu BK, Uyanik F \& Iscan KM. 2008. Effect of dietary oil sources on egg quality, fatty acid composition of eggs and blood lipids in laying quail. South American Journal of Animal Science. 38 (2): 91100

Hartoyo B, Irawan I \& Iriyanti N. 2005. Pengaruh asam lemak dan kadar serat kasar yang berbeda dalam ransum broiler terhadap kandungan kolesterol, HDL dan LDL serum darah. Animal Production. 7(1):27-33.

Hemid, AEA, El-Gawad AAH, El-Wardany I, El-Daly EF \& El-Azeem NAA. 2010. Alleviating effect of some environmental stress factors on productive performance in Japanese quail 2.Laying performance. World Journal of Agricultural Science. 6(5): 517-524
Hilmi M, Sumiati \& Astuti DA.2015. Egg production and physical quality in Coturnix coturnix japonica fed diet containing piperine as phytogenic feed additive. Media Peternakan. 38(3): 150-155

Kamely M, Torshizi MAK \& Khosravinia H. 2016. Omega 3 enrichment of quail eggs: age, fish oil, and savory essensial oil. Journal of Agricultural Science and Technology. 18 (2): 347-359

Khairani, Sumiati \& Wiryawan KG. 2016. Egg production and quality of quails fed diets with varying levels of methionine and choline chloride. Media Peternakan. 39 (1): 34-39

Kurniawan M, Izzati M \& Nurchayati Y. 2010. Kandungan klorofil, karotenoid, dan vitamin $\mathrm{C}$ pada beberapa spesies tumbuhan akuatik. Buletin Anatomi dan Fisiologi. 18(1):28-40

Leeson S \& Summers JD. 2005. Commercial Poultry Nutrition. Third Edition. Canada (CA): Nottingham University Pr.

Li YX, Wang YQ, Pang YZ, Li JX, Xie XH, Guo TJ \& Li WQ. 2011. The effect of crude protein level in diets on laying performance, nutrien digestibility of yellow quails. International Journal of Poultry Science. 10(2): 110-112

Malik AA, Aremu A, Ayanwale BA \& Ijaiya. AT 2016. A Nutritional evaluation of water hyacinth (Eichhornia crassipes. Martius Solms-laubach) meal diets supplemented with Maxigrain* Enzyme for growing pulllets. Journal of Raw Material Research Nigeria. 10(2): 18-44

Mahmood M, Sial AR, Saima, Akram M, Pasha TN \& Jabbar MA. 2014 Effect of dietary energy levels on growth performance and feed cost analysis in Japanese quail. Pakistan Journal of Zoology. 45(5): $1357-1362$

Mangisah I, Tristiarti, Murningsih W, Nasoetion MH, Jayanti ES \& Astuti Y. 2006. Kecernaan nutrien eceng gondok yang difermentasi dengan Aspergillus niger pada ayam broiler. Journal of Indonesian Tropical Animal Agricultural. 31 (2): 124-128

Maulana IT, Sukraso \& Damayanti S. 2014 .Kandungan asam lemak dalam minyak ikan Indonesia. Jurnal Ilmu dan Teknologi Kelautan Tropis. 6(1): 121-130

Metwally AA, El-Gellal AM \& El-Sawaisi SM. 2009). Effect of silymarin on lipid metabolism in rat. World Applied Sciences Journal. 6 (12): 1634-1637

Mona MH, Morsy AS \& Hasan AM. 2013. Egg yolk cholesterol and productive performance of laying hens influenced by dietary crude fiber levels under drinking natural salin water. Journal of Animal and Poultry Production. 4(3): 161-176

Muhammad M, Peter S, James G \& Wosilat A. 2015. Growth performance of growing quails (Coturnix japonica) fed graded levels of Neem. International Journal of Applied Research. 1(2): 04-07

NRC. 1994. Nutrient Requirement of Poultry. 9th Edition. Wahington D.C (US): National Academy

Odo BI \& Nnadi AE. 2014. Growth response of quails (Coturnix coturnix japonica) to varying levels of cassava (Manihot esculenta) tuber meal as a replacement for maize (Zea mays). American Journal of Experimental Agricultural. 4(12): 1898-1903

Riswandi. 2014. Kualitas silase eceng gondok (Eichhornia crassipes) dengan penambahan dedak halus dan ubi kayu. Jurnal Peternakan Sriwijaya. 3(1): 1-6

Rusmana, D. 2007. Pengaruh substitusi minyak sawit oleh minyak ikan lemuru dan suplementasi vitamin E dalam ransum ayam broiler terhadap performans. Jurnal Ilmu Ternak. 7(2): 101-106

Saha S. \& Ray AK. 2011. Evaluation of nutritive value of water hyacinth (Eichhornia crassipes) leaf meal in compound diets for rohu Labeo rohita (Hamilton, 1822) fingerlings after fermentation 
with two bacterial strains isolated from fish gut. Turkish Journal of Fisheries and Aquatic Science. 11: 199-207

Sastrodihardjo S, Suci DM \& Cahyanto MN. 1998. Penggunaan Minyak Ikan Lemuru dan Minyak Kelapa Sawit dalam ransum terhadap Kandungan Asam lemak Omega 3 dan Omega 6 dalam Kuning Telur Ayam. Bogor (ID): Seminar Nasional Peternakan dan Veteriner. Penelitian dan Pengembangan Pertanian

Savory CJ \& Gentle MJ. 1976. Changes in food intake and gut size in Japanese quail in response to manipulation of dietary fibre content. British Poultry Science. 17(6): 571-580

Sotolu AO \& Sule SO. 2011. Digestibility and performance of water hyacinth meal in the diets of African catfish (Clarias gariepinus BURCHELL, 1822). Tropical and Subtropical Agroecosystem. 14: $245-250$

Sim JS, Kitts WD \& Bragg DB. 1984. Effect of dietary saponin on egg cholesterol level and laying hen performance. Canadian Journal of Animal Science. 64: 97-98

Tyagi T \& Agarwal M. 2017. Antioxidant properties and phenolic compound in methanolic extracts of Eichornia crassipes. Reserarch journal of Phytochemistry. 11(2): 85-89.

Tolik D, Polawska E, Charuta A, Nowaczewski S \& Cooper R 2014.Characteristics of egg parts, chemical composition and nutritive value of Japanese quail eggs-a review. Folia Biological (Krakow). 62 (4): 287-292

Tunsaringkarn T, Tungjaroenchai W \& Siriwong W. 2013. Nutrient benefits of quail (Coturnix coturnix japonica) eggs. International Journal of Scientific and Research Publications. 3(5): 1-8 